\author{
O.A. Golovanova, E.S. Chikanova, V.G. Turmanidze \\ F.M. Dostoevsky Omsk State University, Russia \\ (E-mail: golovanoa2000@mail.ru)
}

\title{
The oral fluid chemical composition of professional sportsmen-badminton players
}

\begin{abstract}
We have explored the oral fluid composition and the structural features of qualified sportsmen-badminton players after two interval trainings. It has been established that on all occasions, after the physical activity, the definite $(P=0.95)$ decrease of $\mathrm{Ca}^{2+}$ and glucose is present, the protein and orthophosphate content increases, alkalinization of the saliva occurs, as well as its structural features worsen. We have pointed out that after the second training, there are more significant changes in the chemical composition, with that a sportsman's organism does not restore to originate level and, as consequence, needs appropriate restorative remediation.

Keywords: saliva, oral fluid, sportsmen-badminton players, calcium ions, total protein, glucose, microcrystallization.
\end{abstract}

\section{Introduction}

It is known that the work-out session of a professional sportsman is always connected with growing physical activities. So that it is very important to conduct a package of restorative procedures in time to achieve high results. For the purpose it is necessary to diagnose regularly sportsman's organism state before and after physical activity. Since even small strain may cause disruption of the adaptative powers of organism, the diagnostic methodology should respond to changes in functional status at once.

In this regard, the saliva is the advanced diagnostic fluid in sports and restorative medicine. The oral fluid (saliva) is total secretion of all salivary glands, including also the microflora of the mouth cavity, periodontal pocket contents, crevicular fluids, waste products of soft calculus deposit microflora, the degradation of white blood cells migrated from mucous membrane and discharging with saliva, food debris and etc. It has a variety of advantages [1-3], in the oral fluid, it is possible to measure biomarkers reflecting influence of the stress and the physical activity of varying intensity.

The purpose of the scientific research - exploring of the oral fluid chemical composition and structural features of a group of sportsmen-badminton players before and after the training.

\section{Experimental}

Badminton players of age group of 20-25-year-old took part in the experiment: 4 girls and 6 boys; the athletic title - Master of Sport and Master of Sports of International grade. The experimental subjects' oral fluid was collected into a sterile test glass with close lid within two hours after meal and mouth rinsing with tap water and distilled water during two trainings: before and after strenuous exercise. In the obtained saliva samples we determined $\mathrm{pH}$ medium ( $\mathrm{pH}-150 \mathrm{M}$ ), content of calcium ions [4], orthophosphate-ions [5], protein [6], glucose [7], established type of microcrystallization in accordance with six-point scale (Fig. 1) [8].

The mathematical treatment of all data was carried out with the use of programmes Static2 and Statistica.10 from statistics package StatSoft.

\section{Results and Discussion}

The quantitative characteristic analysis of the saliva composition of sportsmen who are Masters of Sport and Masters of Sports of International grade revealed significant differences in the content of defined components before and after physical activity (Tables 1 and 2).

So, in the course of the training there is alkalinization of the saliva, decrease of calcium ions concentration. The decrease of calcium ions concentration is explained both with outwashing of calcium as a result of the fluid loss and with its direct involvement in energy processes. So, forming organic complexes, it takes part in nerve impulse conduction in muscle cells, and often it is an energy processes catalyst.

Besides, after training the content of orthophosphate-ions increases. Obtained results can be explained by the fact that during strenuous exercise the speed and quantity of oxidable adenosine triphosphoric acid increase, such that orthophosphate acid and large amount of energy product. All of this causes violation of the electrolytic composition of all organism, including the saliva, that has appropriate impact on the change 
of $\mathrm{Ca} / \mathrm{P}$ ratio. In this case it is necessary to elaborate recommendations for the sportsmen of the nutrition which supply the reservoirs of calcium and/or phosphorus next the training.

a

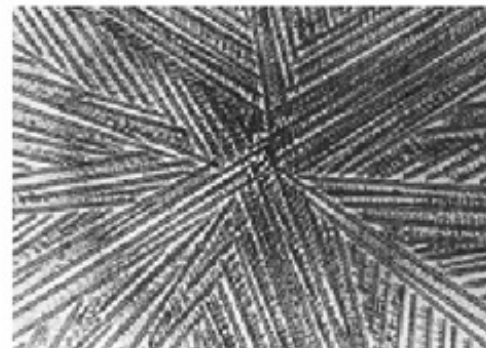

c
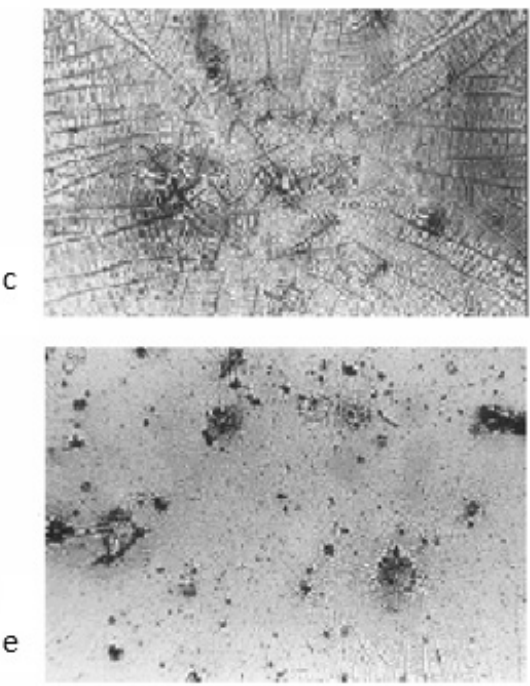

b

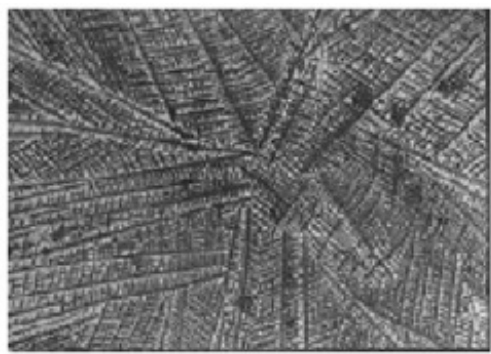

d
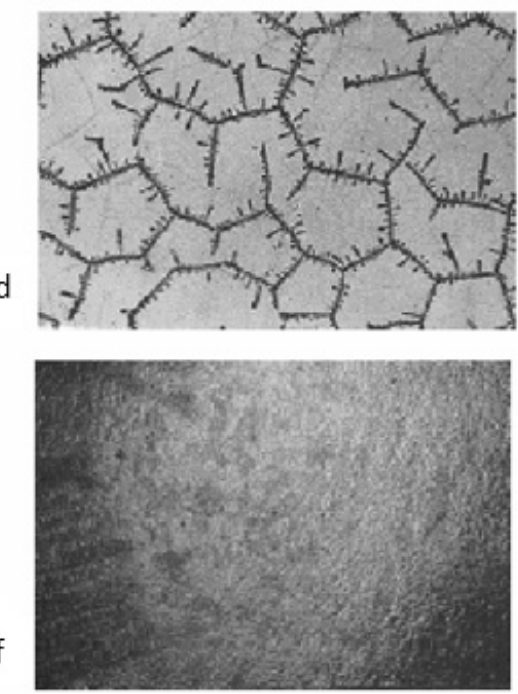

$a-5 ; b-4 ; c-3 ; d-2 ; e-1 ; f-0$ points respectively

Figure 1. Types of microcrystallization

The oral fluid chemical composition of qualified competitive sportsmen (average among the group)

\begin{tabular}{|l|c|c|c|c|}
\hline \multirow{2}{*}{ Criterion } & \multicolumn{2}{|c|}{ Training 1 } & \multicolumn{2}{c|}{ Training 2 } \\
\cline { 2 - 5 } & Before & After & Before & After \\
\hline $\mathrm{pH}$ & $6.8 \pm 0.4$ & $7.9 \pm 0.7$ & $6.6 \pm 0.4$ & $7.8 \pm 0.4$ \\
\hline $\mathrm{Ca}^{2+}, \mathrm{mmol} / 1$ & $3.51 \pm 0.38$ & $2.60 \pm 0.31$ & $3.23 \pm 0.25$ & $2.43 \pm 0.33$ \\
\hline $\mathrm{PO}_{4}{ }^{3-}, \mathrm{mmol} / 1$ & $2.20 \pm 0.22$ & $3.82 \pm 0.25$ & $2.00 \pm 0.22$ & $3.59 \pm 0.27$ \\
\hline $\mathrm{Ca} / \mathrm{P}$ & $1.61 \pm 0.14$ & $0.68 \pm 0.09$ & $1.63 \pm 0.15$ & $0.68 \pm 0.09$ \\
\hline Protein, $\mathrm{mg} / \mathrm{ml}$ & $0.88 \pm 0.09$ & $1.69 \pm 0.10$ & $0.89 \pm 0.10$ & $1.78 \pm 0.13$ \\
\hline Glucose, $\mathrm{mmol} / 1$ & $0.316 \pm 0.024$ & $0.147 \pm 0.039$ & $0.251 \pm 0.028$ & $0.074 \pm 0.018$ \\
\hline
\end{tabular}

Table 2

Changing of basic biological criteria in the process of training, in \%

\begin{tabular}{|c|c|c|}
\hline Criterion & Training 1 & Training 2 \\
\hline $\mathrm{pH}$ & +16.2 & +18.2 \\
\hline $\mathrm{Ca}^{2+}$ & -25.9 & -24.8 \\
\hline $\mathrm{PO}_{4}{ }^{3-}$ & +73.6 & +79.5 \\
\hline $\mathrm{Ca} / \mathrm{P}$ & -57.8 & -58.3 \\
\hline Protein & +92.0 & +100.0 \\
\hline Glucose & -53.5 & -70.5 \\
\hline
\end{tabular}

Note. $«+»-$ increase; $«-»-$ decrease. 
Also, after every activity the total protein content increases significantly, that is connected with remarkable fluid loss of organism.

It is interesting to monitor the change of content of such important carbohydrate as glucose in the course of training. It is known that the main role of the carbohydrates is determined with their energy function. The glucose is an immediate source of energy in organism.

The speed of glucose degradation and oxidation, as well as possibility of extraction from the glucose formation provide urgent mobilization of source of energy under condition of dramatically rising of energy costs, in the cases of emotional exiting, under condition of intense muscular loads and etc. The experimental data (Tables 1 and 2, Fig. 2) show that after significant physical activity the glucose concentrate in saliva decreases more than two times.

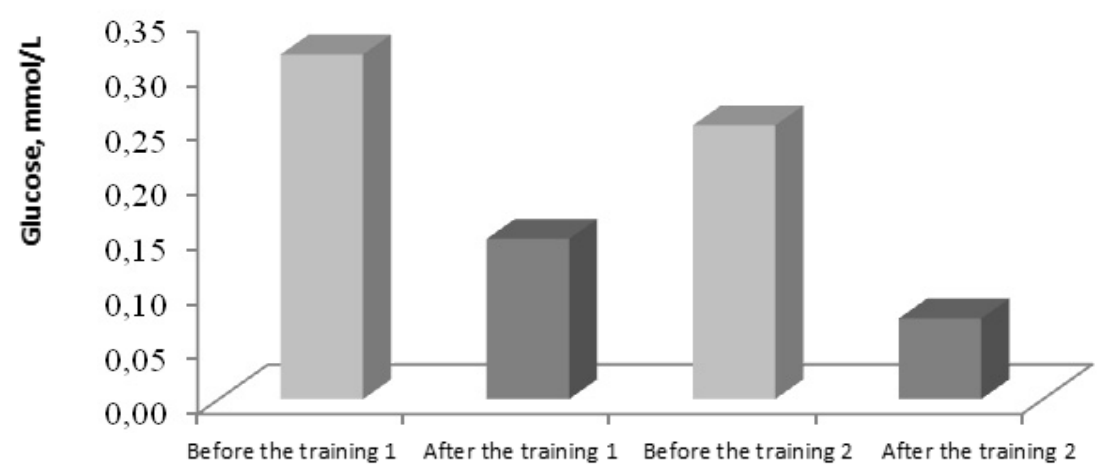

Figure 2. Diagram of glucose concentrate changing in the course of training for the group of competitive sportsmen

Especially significant change is in process of the second training. At this time, there is not original level restoring of glucose content which says about significant energy costs of a sportsman, for that reason it is necessary to supply carbohydrates.

The changes of the content of saliva main components before and after physical activity influenced type of microcrystallization of the oral fluid (Fig. 3-5).

a)

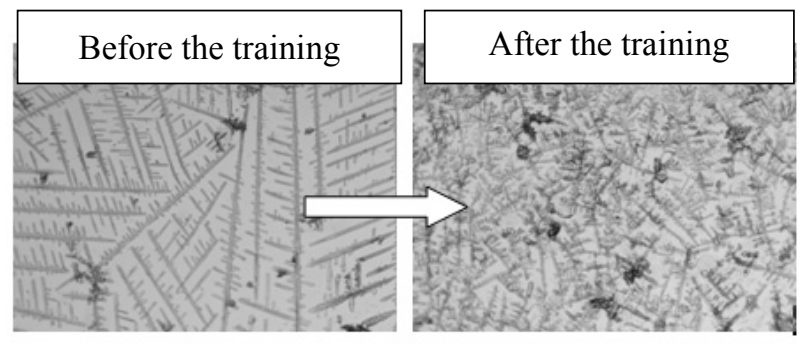

b)

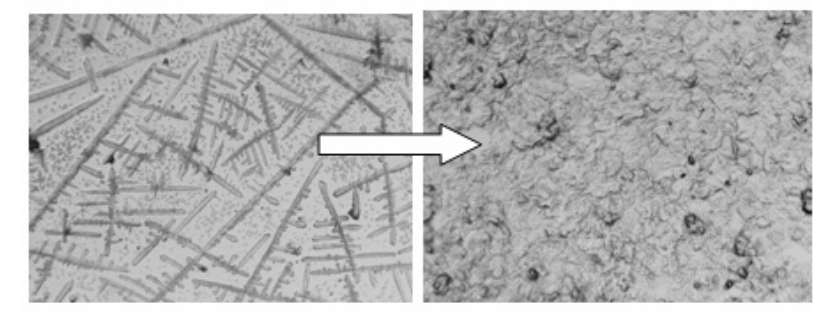

$$
a \text { - training } 1 ; b-\text { training } 2
$$

Figure 3 . The microcrystallization changing in the course of the trainings 


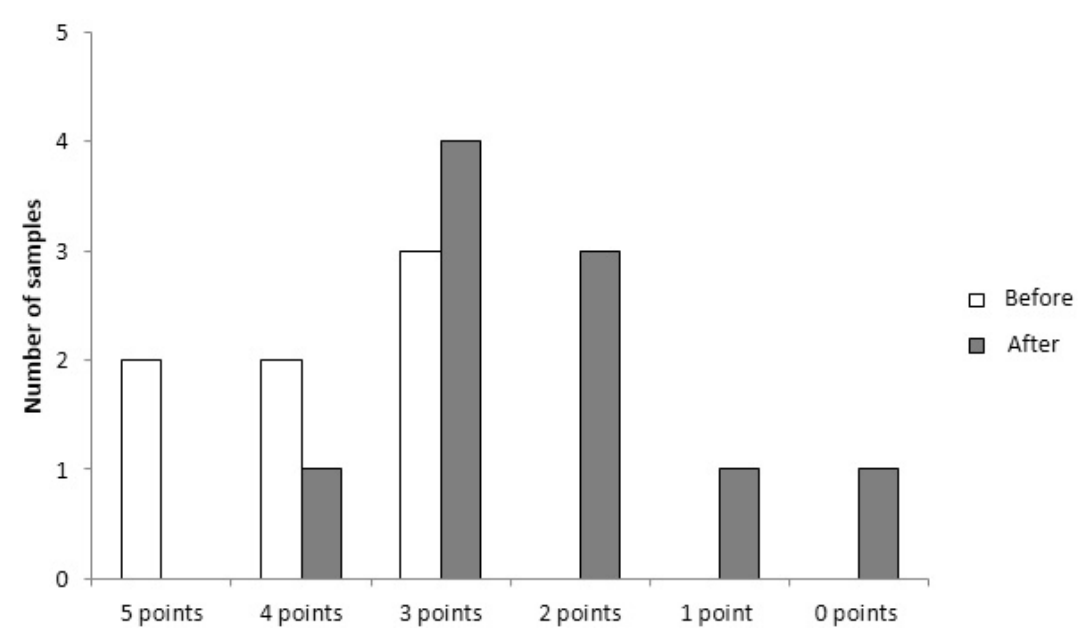

Figure 4. Diagram of type of microcrystallization changing in the course of the training 1

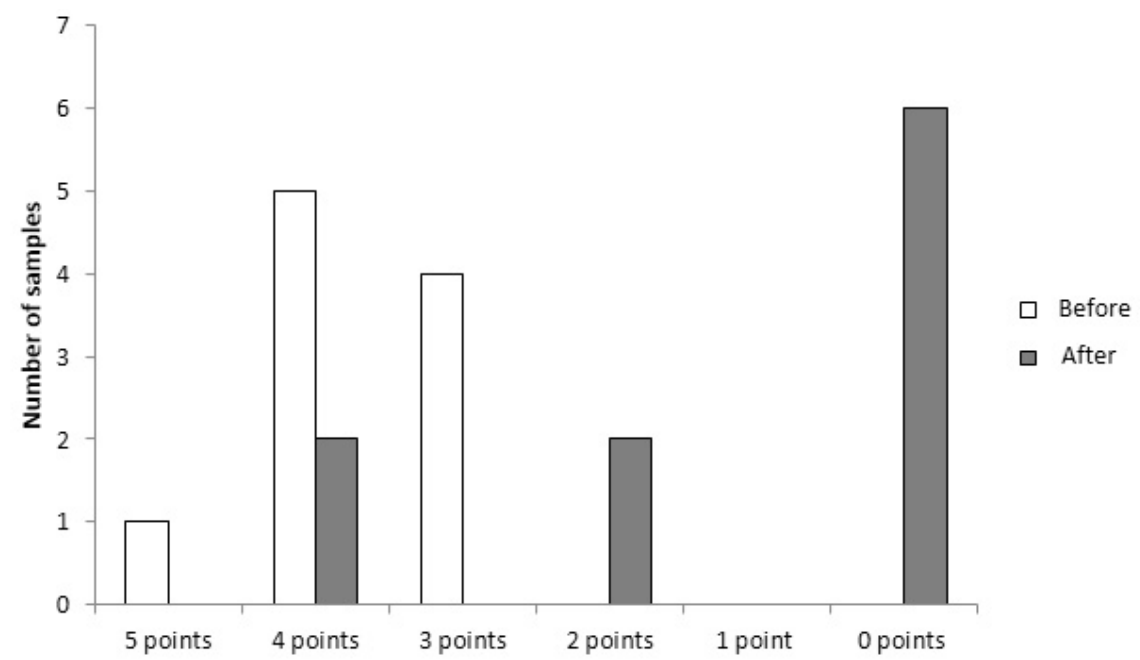

Figure 5. Diagram of type of microcrystallization changing in the course of the training 2

As part of the study, we have found out that after training the crystallization of the oral fluid in principle worsens. The dependences for two trainings are equal but after the second one the changes are more significant.

\section{Conclusion}

So, we have explored the influence of physical activity on the oral fluid composition and the structural properties of a sportsman-badminton player of high qualification. We have examined the perspectives of the use of the data about the composition of human saliva for diagnostic purposes. The possibility of the use of laboratory diagnostics of the physical activity level of human organism with the purpose of finding out of adaptedness level and the organism safety margin has been showed.

\section{References}

1 Чиканова Е.С., Голованова О.А., Турманидзе В.Г. Параметры микрокристаллизации ротовой жидкости спортсменов разных групп // Процессы самоорганизации в высыхающих каплях многокомпонентных жидкостей: эксперименты, теории, приложения: материалы II Междунар. конф. - Астрахань: Изд. дом «Астраханский ун-т», 2012. — С. $167-184$.

2 Шатохина С.Н., Разумова С.Н., Шабалин В.Н. Морфологическая картина ротовой жидкости: диагностические возможности // Стоматология. — 2006. — № 4. — С. 14-17.

3 Ring C., Carroll D., Drayson M. et al. Effects of competition, exercise, and mental stress on secretory immunity // J. Sports Sci. - 2005. - Vol. 23, No. 5. - P. 501-508. 
4 Леонтьев В.К., Петрович Ю.А. Биохимические методы исследования в клинической и экспериментальной стоматологии: метод. пособие. — Омск: Омск. гос. мед. ин-т им. М.И. Калинина, 1976. — С. $32-33$.

5 Больи Д.М., Льюк Ч.Г. Колориметрические методы определения неметаллов / Пер. с англ. — М.: ИЛ, 1963.

6 Практикум по биохимии / Под ред. проф. Н.П. Мешковой и акад. С.Е. Северина. - М.: Изд-во МГУ, 1979.430 с.

7 Thomas L. Clinical Laboratory Diagnostics. — 1st ed. — Frankfurt: TH-Books, 1998. — P. 131-137.

8 Голованова О.А. Биоминералогия мочевых, желчных, зубных и слюнных камней из организма человека: дис. ... д-ра геол.-минерал. наук. — Омск, 2008. - 333 с.

\title{
О.А. Голованова, Е.С. Чиканова, В.Г. Турманидзе \\ Білікті спортшы-бадминтоншылардың ауыз сұйықтығының химиялық құрамы
}

\begin{abstract}
Жұмыс барысында екі аралық жаттығудан кейінгі маманданған спортшы-бадминтоншылардың ауыз сұйықтықтарының химиялық құрылысы және құрамы ерекшеліктері зерттелді. Барлық жағдайда физикалық жүктемеден кейін $\mathrm{Ca}^{2+}$, глюкозаның $\mathrm{C}_{6} \mathrm{H}_{12} \mathrm{O}_{6}$ концентрацияларының анық $(P=0,95)$ төмендегені байқалған, ортофосфаттардың, ақуыздардың құрамы жоғарылайтыны, сілекейдің сілтіленуі жүретіні, сонымен қатар оның құрылыстық қасиеттері нашарлайтыны анықталды. Екінші жаттығудан кейін химиялық құрамда едәуір өзгерістер жүретіні белгілі болды, алайда спортшының ағзасы бастапқыдай қалпына келмейді, сол себепті қалыпқа келу шараларын қажет етеді.
\end{abstract}

Кілт сөздер: сілекей, ауыз сұйықтығы, спортшы-бадминтоншылар, кальций иондары, ортофосфатиондары, жалпы ақуыз, глюкоза, микрокристалдану.

\section{О.А. Голованова, Е.С. Чиканова, В.Г. Турманидзе \\ Химический состав ротовой жидкости квалифицированных спортсменов-бадминтонистов}

\begin{abstract}
В ходе работы изучен химический состав и структурные особенности ротовой жидкости квалифицированных спортсменов-бадминтонистов после двух интервальных тренировок. Установлено, что во всех случаях после физической нагрузки наблюдается достоверное $(P=0,95)$ снижение концентрации $\mathrm{Ca}^{2+}$, глюкозы $\mathrm{C}_{6} \mathrm{H}_{12} \mathrm{O}_{6}$, увеличивается содержание ортофосфатов, белка, происходит подщелачивание слюны, а также ухудшаются ее структурные свойства. Отмечено, что после второй тренировки происходят более значительные изменения в химическом составе, при этом организм спортсмена не восстанавливается до первоначального уровня и, следовательно, нуждается в соответствующих восстановительных мероприятиях.
\end{abstract}

Ключевые слова: слюна, ротовая жидкость, спортсмены-бадминтонисты, ионы кальция, ортофосфатионы, общий белок, глюкоза, микрокристаллизация.

\section{References}

1 Chikanova E.S., Golovanova O. A., Turmanidze V.G. Processes of self-organization in the drying drops of compounding fluids: experiments, theories, appendices: Proceedings of the II International Conference, Astrakhan: Astrakhan University Publ., 2012, p. $167-184$.

2 Shatohina S.N., Razumova S.N., Shabalin V.N. Stomatology, 2006, 4, p. $14-17$.

3 Ring C., Carroll D., Drayson M. et al. J. Sports Sci., 2005, 23, 5, p. 501-508.

4 Leontiev V.K., Petrovich Yu.A. Biochemical diagnostic techniques in the clinical and experimental stomatology: Method book, Omsk: M.I.Kalinin Omsk State Med. Univ. Publ., 1976, p. 32-33.

5 Bolts D.M., Liuk Ch.G. Colorimetric methods of finding out of non-metals: transl. from English, Moscow: Inostrannaya literatura, $1979,275 \mathrm{p}$.

6 Workshop on the biological chemistry, Ed. by Prof. N.P. Meshkova and by Academician S.E. Severin, Moscow: Publ. house of MSU, 1979, $430 \mathrm{p}$.

7 Thomas L. Clinical Laboratory Diagnostics, 1st ed., Frankfurt: TH-Books, 1998, p. 131-137.

8 Golovanova O.A. Biomineralogy of urolith, cholelith, dental calculus, salivary calculus from human organism: Thesis ... of Doctor of Geologic and Mineralogic Science, Omsk, 2008, 333 p. 